\title{
MANAGEMENT OF THE ADAT PERPATIH MATRIARCHY IN NEGERI SEMBILAN
}

\author{
Mohd Rosli Saludin \\ Universiti Kebangsaan Malaysia, Selangor, Malaysia \\ Nor S. Azima Ismail \\ Universiti Kebangsaan Malaysia, Selangor, Malaysia \\ Nor Azean Razali \\ Universiti Kebangsaan Malaysia, Selangor, Malaysia
}

\begin{abstract}
This research is conducted to study the Management of the Adat Perpatih Matriarchy in Negeri Sembilan. The aim of this research is to study the role Ibu Soko (Female Leader) and to discover how Teromba (custom poems) is used as the customary language in the lives of the Malay people in Negeri Sembilan in order to decide on the ideal Ibu Soko. This research is referenced by the Teori Sastera Warisan by A Wahab Ali who wishes to see the legacy preserved indefinitely. It is discovered that there are several forms of Teromba or traditional poetry that focuses on the good leadership of the Ibu Soko that is sourced from the teromba itself. In fact, the poetry being used has its roots traced back to words of the Holy Quran and Hadith of old. This research would be beneficial to the Ibu Soko in question as well as those who wish to practice Adat Perpatih in a way that can be well executed.
\end{abstract}

Key words: teromba (custom poems), ibu soko (Female Leader), Adat Perpatih, Negeri Sembilan.

Cite this Article: Mohd Rosli Saludin, Nor S. Azima Ismail and Nor Azean Razali, Management of the Adat Perpatih Matriarchy in Negeri Sembilan, International Journal of Management, 11(12), 2020, pp. 1527-1536.

http://iaeme.com/Home/issue/IJM?Volume $=11 \&$ Issue $=12$

\section{INTRODUCTION}

The management of Adat Perpatih uses a matrilineal form of administration that focuses more on the female lineage. This defers from the ideals of Adat Tememenggung in which the lineage of the males are put into focus. The communities that practice Adat Perpatih refer to their female leadership as "Ibu Soko". In the administration of Adat Perpatih they (Ibu Soko ) are given the spotlight in almost all aspects of the community. Their status is illustrated by the following verse: 


$$
\begin{aligned}
& \text { Tiang seri rumah pusaka, } \\
& \text { Pusat jala kumpulan tali, } \\
& \text { Semarak dalam kampung, } \\
& \text { Hiasan dalam negeri. }
\end{aligned}
$$

The points to be hit in this research will be focused on the following topics:

- To learn the how Adat Perpatih is managed in Negeri Sembilan with more depth as to how it relates to the teromba (custom poems).

- To learn the how Adat Perpatih is managed in Negeri Sembilan with more depth as to how it relates to the teromba (custom poems).

- To emphasize the importance of the custom itself, especially the management of the Ibu Soko in regards to the preservation of the national legacy.

\section{PREVIOUS RESEARCHERS}

Modern researchers have studied the works of their predecessors who have also run studies regarding the Ibu Soko. The aim of this literary research is to explain in more detail, the results of past studies that have a connection to the current topic. This literary survey is divided in two, which consists of domestic (local) surveys and International surveys. Through the highlights of these questionnaires, researchers will have an easier time giving a more in-depth explanation of the topic being discussed. Aside from that, the information contained in this literary study paper will also give pedestrian readers a more casual experience in parsing the researched information. As a side note from that, this study will also be able to solidify the facts and information gathered by previous researchers

\section{THEORETICAL FRAMEWORK}

This theory will be beneficial in discovering how the supervision of Ibu Soko is done in Adat Perpatih custom. This is due the fact that this theory was based on research of concepts that were passed down through the generations in reference to studies conducted of the "Ibu Soko", a custom that is synonymous with the Adat Perpatih culture especially in the state of Negeri Sembilan. The 'Ibu Soko' title plays a significant role in Adat Perpatih has been passed down through the generations since time immemorial.

The Perpatih community has placed a significant emphasis on the females of the clans. As a result, they have been given first share of all wealth such as houses, land, farms to the women or Ibu Soko. This was done not as a form of female superiority but due to the fact that womenare seen as more vulnerable than men, therefore require more advantages. Men are often regarded as the physically stronger of the two genders and as a result, have been entrus ted with more labour intensive work and higher chance of independance compared to the women. Therefore, most of the inheritance are passed down to the women in the lineage, from mothers to daughters to granddaughters etc.

\section{OBTAINING THE FACT}

\subsection{Women and Perpatih Custom}

The supervision of this custom is based on the community at large and is focused on the cooperation and family values. These concepts are illustrated by the poetry verse below:

$$
\begin{gathered}
\text { Berat sama dipikul, } \\
\text { Ringan sama dijinjing, } \\
\text { Bukit sama didaki, }
\end{gathered}
$$




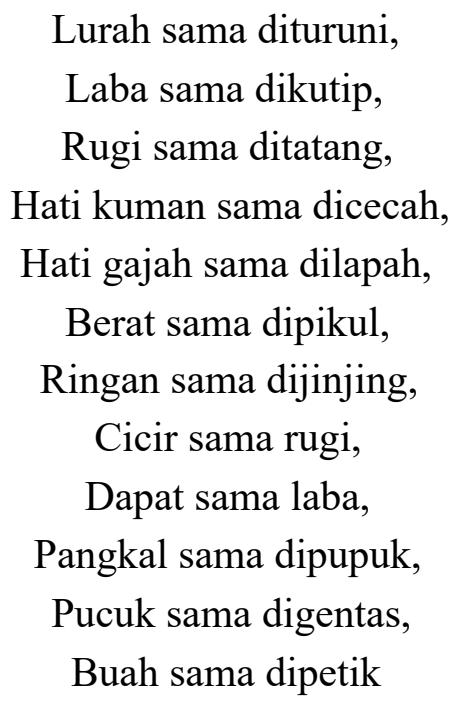

\subsection{Supervision of Women's status in Perpatih Custom}

In traditional context, especially during the years before national independence, the maternal lineage became the base of the social organization, economy and politics in the smaller communities throughout the country. The basis of this system is the continuation of family groups that can only be achieved through a woman's supervision. Therefore, the women in Perpatih custom are given central roles as "Ibu Soko" and are given priority compared to others in the community. Their status is Soko" and are given priority compared to others in the community. Their status is:

\section{Tiang seri rumah pusaka, \\ Pusat jala kumpulan tali, \\ Semarak dalam kampung, \\ Hiasan dalam negeri}

Mr. Abu Bakar also explained that guardian "Ibu Soko" when invited is included in the claim of the guardian "Ibu Soko" and is entitled to their own rewards. There are usually between four or five of the "Ibu Soko' above. The authority of "Ibu Soko" can also be seen in the organizing of important occasions, for example installing the celing curtains, veils etc. This custom is referred to as "Adat Mata" in Perpatih custom. This is also explained by Dato' Rajo Dimuda Ahmad Awalludin who states that all event preparations are supervised by the "Ibu Soko" from the arangements of decorations, food preparation and everything in between. He also adds that there are certain aspects to differentiate "Ibu Soko" from the usual crowd during wedding and engagement events, Ibu Soko will always wear a cloth of songket or Kain Pelikat slung on her shoulder. Mr. Abu Bakar also explains the concept of "Adat Mendangar" in which, during the time of arrival for the wedded couple, gunshots are released. In other parts, fire crackers can also be used in place of guns in order to give the signal.

Sulaiman Akop from Luak Jempol has the opinion that the concept of Ibu Soko is a versatile one and is proving difficult to find in more modern times. The title acts as the matriarch who can educate, teach and point to the heart of a certain community. Ibu Soko who are respected are Ibu Soko who are adept in reaching the hearts of their underling in their respective communities. The burden is also a heavy one as the verse below states:

\footnotetext{
Telah didahulukan selangkah,

Ditinggikan seranting,

Dilebihkan sekuku,
} 


\section{Dipanjangkan seranbut, \\ Beberikan beban berat}

Petuah dan amanah berat.

Puan Halimah Atan from Luak Terachi states that Ibu Soko has a high authority therefore, their power should be exercised carefully and correctly. For example, certain marriage customs are called Olek Betina and Ibu Soko are treated with the utmost priority. This is because they do not wish for Buapak or Lembaga to intervene or be invited whatsoever. It is stated that Ibu Soko will be assisted by Besar Waris.

The "Olek" or wedding custom will still be run as per usual and only with the absence of Buapak and Lembaga. Usually this decision is done unanimously. The higher echelon of the community are the only ones who know why the decision to not include the Buapak and Lembaga was made. In kampung Gentam for example, Oleks in this region only make use of Ibu Soko and Waris Kodin. This was stated by Haji Nasir Abdul Ghani. If the Olek truly wishes to adhere to customary traditions, they would invite the Buapak and Lembaga. This custom has been practiced for generations. If this issue was to be questioned by any party, a meeting of the leadership would be conducted in order to discover the root of the decision. When these situations arise they would useually adhere to the subjectivity of the custom itself and not make it into an objective rule. This situation needs to be resolved in an educated way and thus is the reality that has transpired in the community. It would be simple minded to label an interpretation as false, as different interpretations have different reasons behind them:

$$
\begin{aligned}
& \text { Hati berani senjata tajam, } \\
& \text { Mulu bacar emas banyak, } \\
& \text { Ke laut menuju alur, } \\
& \text { Ke darat menuju benar }
\end{aligned}
$$

Haji Abdullah Suboh from Luak Sungai Ujong stated that the Ibu Soko should have the best of qualities and standards in order for Adat Perpatih to be successful. The qualities of a good Ibu Soko are listed below:

- Just- have a sense of truth and justice in their daily lives and their actions.

- Honest - have a sense of honesty, be trustworthy and not adhere to qualities stated in the verse below:

$$
\begin{gathered}
\text { Pepat di luar, } \\
\text { Rencung di dalam }
\end{gathered}
$$

Telunjuk lurus

Kelingking berkait

$$
\begin{aligned}
& \text { Kok keruh di hulu } \\
& \text { Sampai ke muara keruhnya }
\end{aligned}
$$

$$
\begin{gathered}
\text { Kok kurik induknya } \\
\text { Rintiklah anaknya. }
\end{gathered}
$$

- Just- have a sense of truth and justice in their daily lives and their actions.

- Inheritor of wealth - Land or estate is the most important inheritance. Land is seen as the quintessential wealth during hard times. Its importance is stated in the verse below: 
Terbit pesaka kepasa sako,

Lelaki menyandang pusaka,

Soko berjejak di atas pesaka,

Orang semenda menjaga,

Dan membela adat dan pesaka.

- Ibu Soko should be aware of the situations of their male relatives, as well as the females. Though the women are usually in favour of inheritance, both should play equal importance in order for the community to succeed:
Aur dengan tebing
Ijok dengan soga
Kok hilang dicari
Kok cicir dipungut
Kok hanyut dipinteh
Kok luka ditasak
Kok sakit diubatkan
Kok haus diberi air
Kok litak diberi nasi
Kok hidup dibela
Kok mati ditanam

- If a man lost his wife in death, it is the responsibility of the Ibu Soko or their female relatives to invite them back in as the male heirs.

Dahulu datangnya dijemput dengan adat

Perginya dihantar sepanjang adat

Justeru

Untung nan melambung

Malang nan menimpa

Kok ke laut pecah perahu

Kok ke darat pecah periuk

Kok sirih pulang ke gagang

Kok pinang nak pulang ke tampuk

Belut nak pulang ke lumpur

Anak buah nak pulang ke warisnya.

- Ibu Soko are entitled to be involved in all processes of a certain event albeit, a wedding engagement, etc.

\section{Bulat Ibu Soko}

Rapat waris-waris berpesaka

Melantik penyandang-penyandang pesaka adat

Juga menurunkannya.

\section{Meaning:}

In the process of picking an heir, Ibu Soko is key in deciding those who are worthy of inheritance. Ibu Soko will list out the names of the potential heirs based on their qualities given to her by her assistants, whether it be their lack of admiration towards tradition, their knowledge 
and practice of it in their daily lives, etc. When a consensus is reached, Ibu Soko will nominate the selected heirs among the circle of relatives. Through consensus, Ibu Soko also reserves the right to strip the title of inheritance.

\author{
Ibu Soko \\ Penyeri rumahtangga \\ Semarak kampung, kota dan negeri
}

The number of Ibu Soko in a certain sect of the community is low and only as many as 3 Ibu Soko may be present at one time. They are the women of Adat Perpatih who are very knowledgeable of the custom itself. They are able to reference the customs of the Adat Perpatih by heart as they have studied it intensively. These Ibu Soko have tremendous amount of experience that they learn from their surrounding environments. According to the verse:

Panakik pisau siraut

Ambil galah batang lintabung

Selodang jadikan nyiru

Air nan setitik jadikan lautan

Tanah nan sekepal jadikan gunung

Alam terkembang jadikan guru.

During traditional events, the influence of Ibu Soko are obvious and even more so during loud and celebratory events such as weddings. The Ibo Soko will supervise all aspects of the occasion from the decorations, wedding veils, guests, food preparation and the wedding ceremony itself. All of these are in place as traditional customs. In supervising these events it is crucial for the Ibu Soko to be supplied the required tools and infrastructure. The Ibu Soko has the right to punish the homeowner if these requirements are not met for the required ceremony. Buapak will do as is told and will fulfil their given roles. The Buapak themselves will refer to the Ibu Soko in regards to the customs that need to be practiced. It is clearly stated under that supervision:

\title{
Lelaki nan penyandang pesaka \\ Perempuan nan punya pesaka
}

\subsection{Women's responsibility in supervising the Perpatih customs}

The responsibilities of women are quite vast both as the Ibu Soko and as Peti Benian to their own respective family groups. Among those responsibilities are:

- Performing religious and traditional customs

Every woman in Adat Perpatih represent a family lineage and a maternal example to their respective families and communities. Therefore, they will be examples and leaders of the newer generations and should be good role models in terms of religious acts and traditional customs. They should reserve their ideals according to the following verse:

Adat bersendikan syarak

Syarak bersendikan kitabullah

- Responsible towards the continuation of their respective family lineage.

Every child born are entitled to the side of the mother's family instead of the father. Due to this, relations with the maternal side of the family is the stronger one. Furthermore, the socialization and upbringing of the child ar more influenced on the mother's side of the family.

- Responsibility in making sure their progeny become model citizens of the community. 
- Taking care of their family inheritance.

Women of tradition are already taught with an economic mind set. Therefore, their responsibility towards handling their wealth is as important if not more important than the previous responsibilities mentioned above. During farming season, it is the women who handle the bulk of the activities.

- Responsibility towards their heirloom homes and land.

The women of Adat Perpatih have, in their inventory, their own house, paddy fields, land and farms. Strictly, the women are generally the owners of their respective wealth and land but the men are responsible for working, managing and expanding their wealth for their future generations of children. On the other hand, though the women are responsible for the wealth and administration, in terms of home life and marriage, it is the husbands who are responsible for being the leader of their own families. This situation is recorded as follows:

Bendul yang empat,

Semenda nan punya.

\subsection{Women in supervising their community structure}

This principle relies on the marriage of men and women from different familial clans in order to build a diplomatic relation between them. This relationship will ensure the growth of both their respective clans. Due to this, there are no conflicts between different familial groups.

$$
\begin{gathered}
\text { Alam beraja, } \\
\text { Luak berpenghulu, } \\
\text { Suku bertua, }
\end{gathered}
$$

Anak buah beribu bapa,

Orang semenda bertempat semenda

Raja menobat di dalam alam,

Penghulu menobat di dalam luak

Lembaga menobat di dalam lingkingannya,

Buapak menobat pada anak buahnya,

Orang banyak menobat di dalam terataknya.

Through the words above, illustrating a social order can be achieved through tight-knit social principles through family lineage and marriage and also through the principles of provincial politics. The supervision of Adat Perpatih dictates that every individual is a member of their respective family, clan state etc. The basis of familial relations and marriage connects them on a basic level except for families or households that are very restricted and limited. Individuals are considered as strangers to familial groups that are not theirs. Within the Adat Perpatih community, these familial ties are considered to be very tight-knit and welcoming especially between siblings and hereditary bonds. This is the importance of knowing the family lineage on the women's side.

\subsection{Women in handling inheritance}

Women act as the family guardian but if the situation arises where the husband and wife are divorced, the woman is forced to be able to fend for herself and be independent. If the woman becomes a widow but is still wealthy, she has a better chance in living her day-to-day life. This is due to the fact that some widows have farms and sizeable amount of farmland in their 
possession and can therefore, generate their own livelihood from the wealth of land that they possess.

- Inheritance

- Livelihood

- Carrier Property

- Income

Women inherit the wealth, and is entitled to the wealth that she has inherited as well as being obligated towards the administration and handling of said inherited wealth. Her first responsibility is the protection of those in their immediate families as well as others with whom they share a blood relation with. This is recited in the following verse:

\title{
Cicir dipungut,
}

Hilang dicari,

Nyawa darah waris yang punya,

Rugi laba isteri yang punya.

The next responsibility is the expenditure for the wedding ceremony during a marriage as well as the forfeits that arise from the wedding ceremony itself. No one is allowed to forfeit their heirloom belongings for the purpose of paying for any expenditure aside from four reasons. This is illustrated in the verse below:

Adat pusaka tak berdiri,

Rumah gadang ketirisan,

Gadis gadang tak berkaki,

Mayat terbujur di tengah rumah.

\subsection{Supervision of income for married couples}

The system of inheritance of personal income is dictated by the following verse:

Putus belah seorang beragih,

Cari bahagi,

Dapatan tinggal,

Bawaan kembali.

The division of the inheritance to the heir of the deceased is dependent on the form of said wealth. If the deceased is a single person or a widow, the wealth is divided to their familial groups or descendants. Generally it is the females of the family who will be the heir. If the wealth is that of a husband and wife, the surviving spouse will inherit the wealth. If the husband passes away, the wife inherits it and the opposite is true if the wife passes away first. The surviving husband is responsible for taking care of and saving the wealth to be inherited to their male or female children. Should both parties are the deceased, the wealth will be inherited to both their respective families. The inheritance of the married couple's wealth is highlighted in the following verse:

\author{
Carian bahagi, \\ Mati laki tinggal ke bini, \\ Mati bini tinggal ke laki, \\ Mati laki bini tinggal ke anak
}




\subsection{Supervision system of marriage property}

Marriage property consist of the wealth of both parties. When a divorce occurs, the wealth generated at the beginning of the marriage will be divided back to both spouses. Therefore, carried property will be distributed to the husband and found property to the wife. Income property will be distributed to both parties regardless of who is at fault or how many children the couple has. The system of supervision for the distribution of marital wealth can be illustrated by the following verse:

\section{CONCLUSION}

Adat pertemuan dinikahi,

Habis pertemuan dicerai,

Carian dibahagi,

Dapatan tinggal,

Pembawa kembali,

Pembawa kembali,

Dapatan tinggal,

Carian dibahagi

Mati laki tinggal ke bini,

Mati bini tinggal ke lak

This research is crucial in the conservation of the female supervision in Adat Perpatih so the traditions and customs can be carried forward into modernity. On another note, this research paper is also made to parse the information on the Ibu Soko custom and to educate common folk in the ways and traditions of Ibu Soko in the Perpatih custom. It is clear how crucial the role of Ibu Soko is in the Adat Perpatih community in all of its facets from administration to handling its various events and ceremonies in their respective familial groups and clans. The hope of this research paper is to educate those who are interested in learning the intricacies and responsibilities of women within the Adat Perpatih.

\section{REFERENCES}

[1] Abdul Halim Ali (2006), Ikhtisar Teori dan Kritikan Sastera: Barat dan Malaysia. Tanjung Malim: Penerbit Profesional Baharu.

[2] Azizah Kassim (1974). Kedudukan Wanita dalam Masyarakat Adat Perpatih dalam Abad Kedua Puluh. Manusia dan Masyarakat. Kuala Lumpur: Universiti Malaya.

[3] Mohd. Rosli Saludin (2005), Teromba bersama Dr. Mohd. Rosli Saludin. Siri Warisan Negeri Sembilan Darul Khusus, Jabatan Kebudayaan, Kesenian dan Negeri Sembilan.

[4] Kamus Dewan Edisi keempat (2007). Kuala Lumpur: Dewan Bahasa dan Pustaka.

[5] Mana Sikana (1998). Teori dan Pendekatan Kritikan Sastera Moden. Shah Alam: Penerbit Fajar Bakti Sgn Bhd.

[6] M.Nasroen (1971). Dasar Falsafah Adat Minangkabau. Bulan Bintang: Jakarta

[7] Mohammad Din Bin Ali (1956). Sambaan Cakap dan Perpatih Adat Melayu. Kuala Lumpur The Economy Printers Ltd. 
[8] Mohd. Rosli Saludin (2005), Teromba bersama Dr. Mohd. Rosli Saludin, Siri Warisan Negeri Sembilan Darul Khusus, Jabatan Kebudayaan, Kesenian dan Negeri Sembilan.

[9] Mohd. Rosli Bin Saludin (2007). Naning Luak Terbilang. Penang: Goal Intelligent Publishing Sdn Bhd.

[10] Norazit Selat (1990). Negeri Sembilan Dahulu dan Sekarang, Muzium Negara Kuala Lumpur.

[11] Nordin Selat (2007). Sistem Sosial Adat Perpatih. Kuala Lumpur: Utusan Publications \& Disrtributors Sdn Bhd.

[12] Norhalim Hj. Ibrahim (1994). Wanita: Antara Setia dan Air Mata. Kajang: Masa Interprise.

[13] Norhalim Hj. Ibrahim (1995). Negeri yang Sembilan. Selangor: Fajar Bakti Sdn Bhd.

[14] Norhalim Hj, Ibrahim (1996). Perkahwinan Adat di Negeri Sembilan. Shah Alam: Penerbit Fajar Bakti Sdn Bhd. 